\title{
Flushing Ewes on Chemically Cured Hill Pastures
}

\author{
D.L. TART AND S.H. SHARROW
}

\begin{abstract}
A study was conducted to evaluate the use of chemically cured pasture as a flushing feed for ewes in western Oregon. In 1976 paraquat $(0.28 \mathrm{~kg} / \mathrm{ha})$ was used to chemically cure hill pasture forage when perennial ryegrass (Lolium perenne $L$.) and tall fescue (Festuca arundinacea Schreb.) were in early anthesis. Crossbred ewes grazed the pastures from 17 days after the start of mating. Forage a vailable during the breeding season had a higher protein content $(P<.50)$ on paraquat-treated than on untreated pasture. Paraquat treatment had no effect, however on forage dry matter digestibility $(P<.05)$. Chemical curing greatly reduced herbage yield, probably due to increased shattering and decomposition losses. Summer rainfall may have intensified the latter problem. Using chemically cured forage as flushing feed did not improve ewe live weight gains or lambing performance over untreated forage. Therefore, flushing ewes on chemically cured pasture appears to have little potential in areas, such as western Oregon, where summer rainfall is likely to occur.
\end{abstract}

The production cycle of many western Oregon sheep operations requires that ewes be bred during the summer dry forage period, when nonirrigated pastures are lowest in nutritional value (Hedrick 1957). Since high quality pasture is generally not available for flushing ewes, supplemental feeds are often provided during the breeding season. Rapid desiccation of green forage by quick-acting herbicides, such as paraquat, has been observed to preserve the nutritive quality of treated forage, thus improving the nutrient content of the dry forage available during the summer in Mediterranean environments (Sneva 1967, Arnold et al. 1970, Kay 1970, Kay and Torell 1970, Arnold and Barret 1974). Such chemically cured forage has been suggested as a possible low-cost alternative to hay, grain, or other supplemental feeds (Arnold et al. 1970, Barret et al. 1973a). The purpose of this study was to evaluate the quantity and quality of forage on offer and the performance of ewes bred on chemically-cured hill pastures in western Oregon.

\section{Study Area and Methods}

This investigation was conducted on pastures located in the foothills of the Coast Range near Corvallis, Oregon. Elevation is approximately $90 \mathrm{~m}$. The climate is a mild, subcoastal type with moist winters and mild, dry summers. Annual precipitation is 102 $\mathrm{cm}$. Soils were Bashaw series (Typic Pelloxerets; S.C.S., 1975). Dominant forage species were perennial ryegrass (Lolium perenne L.), tall fescue (Festuca arundinacea Schreb.), and subclover (Trifolium subterraneum $\mathrm{L}$.).

A 3-ha pasture was treated with $0.28 \mathrm{~kg} / \mathrm{ha}$ of paraquat on June 3 , 1976. Both perennial ryegrass and tall fescue were in early anthesis at the time of spraying. Paraquat application was made using a carrier volume of 4681 / ha of water with X-77, a surfactant, added at $0.05 \%$ by volume. Adjacent, untreated, 3-hectare pasture

\footnotetext{
At the time of research, authors were research assistant and assistant professor Rangeland Resources Program, Oregon State University, Corvallis 97331.

The authors gratefully acknowledge the help of $\mathrm{Mr}$. Glen Savelle who developed the concept of this study, the donation of the paraquat by the Chevron Chemical Company, and the loan of the sheep used in 1975 by the Superior Packing Company, Inc; $\mathrm{C} 2 \mathrm{~L}$, Inc.; and Mr. Phil Cohn of Ellensburg, Washington.

This report is Oregon Agr. Exp. Sta. Tech. Paper No. 5681

Manuscript received November 10, 1980.
}

served as a control. Both pastures were sampled to determine forage quantity and quality before sheep were turned in (August 25), midway through the grazing period (September 8), and immediately after the grazing period (October 4). On each sampling date, twenty $0.1 \mathrm{~m}^{2}$ plots were harvested from each pasture. Herbage samples were sorted into dry herbage and regrowth, then oven-dried at $50^{\circ} \mathrm{C}$ for 48 hours and weighed. Samples were then ground to pass a $40-$ mesh screen. Crude protein and dry matter digestibility of herbage samples was evaluated using micro-Kjeldahl (A.O.A.C. 1965) and in vitro rumen fermentation (Daugherty 1979) procedures, respectively. Forage data were analyzed by analysis of variance (split plot over time) procedures (Steel and Torrie 1960).

In a completely randomized design, 37 yearling crossbred ewes and 48 ewe lambs were stratified by age and assigned to the pastures. Ewes were split between the paraquat-treated and control pastures so that each was stocked with 14.2 ewes/ha. Flushing (grazing) began on August 27, 1976, and continued for 34 days. Each group had access to water and trace-mineralized salt but received no other supplemental feed. Rams were introduced into each group halfway through the flushing period. After the flushing period the groups were pooled on the unsprayed pasture, and the rams were left with the ewes another 17 days. Ewes were weighed at approximately weekly intervals throughout the flushing period.

Live weight change and lambing performance of ewes were analyzed using analysis of variance and Chi-square contingency tables, respectively (Steel and Torric 1960).

\section{Results and Discussion}

Herbage yield was lower $(P<.05)$ on the paraquat-treated than on the control pasture (Table 1). Field observations indicated that paraquat made plants brittle, resulting in considerable shattering losses. Arnold and Barrett $(1974,1978)$ also noted brittleness in paraquat-treated herbage. However, chemical curing does not always increase susceptibility to shattering (Kay and Torell 1970, Sneva and Gomm 1979). This effect may vary with plant species, phenology, and application rate. In this study, the treated herbage was beaten down by wind and rain and tended to retain moisture. Total herbage yield on the treated pasture declined by $31 \%$ during the 2 months prior to the grazing period, during which time $6.3 \mathrm{~cm}$ of rainfall was recorded. Since the forage lost was not visible as litter, much of the decline was apparently due to either decomposition or removal of shattered material by wind. Sneva (1967) and

Table 1. Effect of paraquat treatment on herbage yield $(\mathrm{kg} / \mathrm{ha})$ in 1976.

\begin{tabular}{lccccc}
\hline \hline & \multicolumn{2}{c}{ Total herbage } & & \multicolumn{2}{c}{ Regrowth } \\
\cline { 2 - 3 } Time & Control & Treated & & Control & Treated \\
\hline 23 days post-treatment & & 4045 & & \\
Pre-grazing & $4407^{\mathrm{a}} 1$ & $2783^{\mathrm{b}}$ & & $1125^{\mathrm{a}}$ & $425^{\mathrm{b}}$ \\
Mid-grazing & $3542^{\mathrm{a}}$ & $1388^{\mathrm{b}}$ & & $829^{\mathrm{a}}$ & $165^{\mathrm{b}}$ \\
Post-grazing & $2652^{\mathrm{a}}$ & $1215^{\mathrm{b}}$ & & $423^{\mathrm{a}}$ & $102^{\mathrm{b}}$ \\
\hline
\end{tabular}

${ }_{1, \mathrm{a} b}$ Means in the same row with unlike superscripts differ significantly $(P<.05)$. Comparisons are not intended between total herbage and regrowth. 
Table 2. Effect of paraquat treatment on crude protein content and in vitro dry matter disappearance of forage.

\begin{tabular}{|c|c|c|c|c|c|c|c|c|c|}
\hline \multirow[b]{3}{*}{ Time } & \multirow[b]{3}{*}{ Date } & \multicolumn{4}{|c|}{ Percent crude protein } & \multicolumn{4}{|c|}{ Percent in vitro dry matter disappearance } \\
\hline & & \multicolumn{2}{|c|}{ Mature herbage } & \multicolumn{2}{|c|}{ Regrowth } & \multicolumn{2}{|c|}{ Mature herbage } & \multicolumn{2}{|c|}{ Regrowth } \\
\hline & & Control & Treated & Control & Treated & Control & Treated & Control & Treated \\
\hline $\begin{array}{l}\text { Pre-grazing } \\
\text { Mid-grazing } \\
\text { Post-grazing }\end{array}$ & $\begin{array}{c}8 / 25 \\
9 / 8 \\
10 / 4\end{array}$ & $\begin{array}{l}4.6^{\mathrm{a}_{1}} \\
4.9^{\mathrm{a}} \\
3.8^{\mathrm{a}}\end{array}$ & $\begin{array}{l}8.2^{\mathrm{b}} \\
7.4^{\mathrm{b}} \\
6.5^{\mathrm{b}}\end{array}$ & $\begin{array}{l}7.4^{\mathrm{a}} \\
6.3^{\mathrm{a}} \\
8.1^{\mathrm{a}}\end{array}$ & $\begin{array}{r}10.9^{\mathrm{a}} \\
9.5^{\mathrm{a}} \\
12.3^{\mathrm{b}}\end{array}$ & $\begin{array}{l}23^{\mathrm{a}} \\
23^{\mathrm{a}} \\
20^{\mathrm{a}}\end{array}$ & $\begin{array}{l}19^{\mathrm{a}} \\
16^{\mathrm{a}} \\
15^{\mathrm{a}}\end{array}$ & $\begin{array}{l}44^{\mathrm{a}} \\
41^{\mathrm{a}} \\
47^{\mathrm{a}}\end{array}$ & $\begin{array}{l}41^{\mathrm{a}} \\
38^{\mathrm{a}} \\
44^{\mathrm{a}}\end{array}$ \\
\hline
\end{tabular}

${ }_{1 \mathrm{a}, \mathrm{b}}$ Means in the same row with unlike superscripts differ significantly $(P<.05)$. Comparisons are not intended between mature herbage and regrowth

Pullman and Allden (1971) reported similar losses. Greater regrowth on the control pasture after the time of application also contributed to the large differences in total pre-grazing herbage yields (Table 1).

The protein content of the chemically cured (mature) forage was higher $(P<.05)$ than the control throughout the grazing period (Table 2). This difference probably resulted in part from the dessication of forage at a phenologically earlier stage on paraquattreated pastures and in part from a higher clover content of herbage present on paraquat-treated pasture. Mature herbage on the control pasture was $6.9 \%$ clover, while that on the treated pastures averaged $18.3 \%$ clover (based on ocular estimates for mature herbage samples). Pre-grazing protein yields of the treated control pastures were similar, however ( 286 and $274 \mathrm{~kg}$ protein/ ha for control and treated pastures, respectively; $P<.05$ ), indicating that higher protein content tended to compensate for the lower dry matter yield of the paraquat-treated pasture. Kay and Torell (1970) observed similar results. In other studies, however, chemical curing increased protein yield even though herbage yield was greatly reduced (Arnold et al. 1970, Sneva 1973).

Paraquat treatment had no effect $(P>.05)$ on in vitro dry matter digestibility (Table 3 ). This result is consistent with those of other workers who have also noted little influence of paraquat treatment on dry matter digestibility for a variety of pasture types (Wallace et al. 1966, Romberg et al. 1969, Pullman and Allden 1971, Arnold and Barrett 1974). The dry matter digestibility values obtained in this study appeared to be somewhat low, possibly because of the one-stage digestion procedure used.

The number of lambs born per ewe and the number of ewes bearing la mbs did not differ $(P>.05)$ between experimental groups (Table 3). From the animal performance data reported here, it appears unlikely that a flushing response (significant increase in percent lamb crop as a result of an elevated plain of nutrition at breeding) occurred in either group of ewes.

Live weight gains on both the paraquat-treated and control pastures were low (Table 3). Animal performance on the control pasture was probably limited by percent crude protein content of the forage on offer which was below NRC (1975) requirements (9.5\% crude protein) for yearling ewes and ewe lambs throughout the grazing period (Table 2). The paraquat-treated pasture, on the

Table 3. Effect of paraquat treatment on the performance of ewes.

\begin{tabular}{|c|c|c|c|c|}
\hline \multirow[b]{2}{*}{ Item } & \multicolumn{2}{|c|}{ Yearlings } & \multicolumn{2}{|c|}{ Ewes Lambs } \\
\hline & Control & Treated & Control & Treated \\
\hline Initial weight ( $\mathrm{kg} /$ ewe) & $48.0^{a_{1}}$ & $48.0^{a}$ & $41.3^{\mathrm{a}}$ & $40.3^{a}$ \\
\hline Final weight $(\mathrm{kg} / \mathrm{ewe})$ & $52.4^{\mathrm{a}}$ & $52.1^{\mathrm{a}}$ & $41.3^{\mathrm{a}}$ & $40.2^{n}$ \\
\hline $\begin{array}{l}\text { Average daily gain } \\
(\mathrm{kg} / \text { ewe/day })\end{array}$ & $0.13^{a}$ & $0.12^{\mathrm{a}}$ & $0^{a}$ & $0^{\mathrm{a}}$ \\
\hline No. of ewes & 19 & 18 & 24 & 24 \\
\hline No. of dry ewes & 0 & 0 & 9 & 9 \\
\hline No. of single births & 5 & 10 & 9 & 11 \\
\hline $\begin{array}{l}\text { No. of multiple births } \\
\% \text { ewes bearing during } \\
\text { first } 17 \text { days of } \\
\text { lambing }\end{array}$ & 14 & $82^{\mathrm{a}}$ & $39^{\mathrm{b}}$ & $40^{\mathrm{h}} \mathrm{b}$ \\
\hline $\begin{array}{l}\text { Lambs born per ewe } \\
\text { present }(\%)\end{array}$ & $168^{\mathrm{a}}$ & $144^{\mathrm{a}}$ & $92^{b}$ & $79^{\mathrm{b}}$ \\
\hline $\begin{array}{l}\text { Lambs born per ewe } \\
\text { bearing }(\%)\end{array}$ & $168^{\mathrm{a}}$ & $144^{\mathrm{a}}$ & $147^{a}$ & $136^{\mathrm{a}}$ \\
\hline
\end{tabular}

other hand, had regrowth which was adequate in percent crude protein (Table 2), but relatively little forage dry matter on offer (Table 1). It is proposed, therefore, that while animal performance on the two pastures was similar $(P>.05)$, the factors limiting animal performance were quite different: crude protein intake on the control pasture vs. digestible dry matter intake on the paraquat-treated pasture.

\section{Management Implications}

Under the summer climatic conditions experienced in this study, the use of chemically cured pasture as flushing feed did not improve ewe live weight gains or lambing performance. The increase in protein content produced by paraquat treatment appeared to have been offset by yield losses, probably due to shattering and decomposition. Therefore, chemical curing appears to have little potential in areas with maritime climates where summer rainfall is likely to occur, such as western Oregon, western Washington, and coastal northern California. In addition, the relatively poor performance of ewes on both paraquat-treated and control pastures indicates that flushing responses should not be expected on similar pastures unless supplemental feed is provided.

\section{Literature Cited}

A.O.A.C. 1965. Official Methods of Analysis. 10th Ed. Association of Agricultural Chemists. Washington, D.C. 957 p.

Arnold, G.W., and D.W. Barrett. 1974. The effect of paraquat desiccation in spring on plant and animal production from annual pastures. Australian J. Exp. Agr. Anim. Husb. 14:23-32.

Arnold, G.W., and D.W. Barrett. 1978. Comparative nutritive value of hay made normally and by desiccation with paraquat. Australian J. Exp. Agr. Anim. Husb. 18:539-545.

Arnold, G.W., D.W. Barrett, P. Lapins, and J. Whitehead. 1970. Some effects of paraquat on yield of dry matter and nutrients, and on sheep production from annual pastures. Proc. 115th Internat. Grassl. Cong., Surfer's Paradise, p. 866-869.

Daugherty, D.A. 1979. The effects of urea supplementation on feather meal and hair utilization by ruminants. M.S. thesis. Oregon State Univ., Corvallis, Ore. 62 p.

Kay, B.L. and D.T. Torell. 1970. Curing standing range forage with herbicides. J. Range Manage. 23:34-41.

National Research Council. 1975. Nutritional requirements of sheep. Nat. Acad. Sci., Washington, D.C.

Pullman, A.L., and W.G. Allden. 1971. Chemical curing of annual pastures in southern Australia for beef cattle and sheep. Australian J. Agr. Res. 22:401-413.

Romberg, B., G.R. Pearce, and D.E. Tribe. 1969. The effect of chemical curing with paraquat on the intake and digestibility of phalaris pasture. Australian J. Exp. Agr. Anim. Husb. 9:71-73.

Scott, G.E. (ed.) 1970. The Sheepman's Production Handbook. Sheep Industry Development Program, Inc. 226 p.

S.C.S. 1975. Soil Survey of Benton County Area, Oregon. U.S.D.A. Soil Conservation Service. Washington, D.C. 119 p.

Sneva, F.A. 1967. Chemical curing of range grasses with paraquat. J. Range Manage. 20:389-394.

Sneva, F.A. 1973. Nitrogen and paraquat saves range forage for fall grazing. J. Range Manage. 26:294-295.

Sneva, F.A., and F.B. Gomm. 1979. Time and rate of paraquat application for curing meadow vegetation for winter grazing. Agron. J. 71:634-638.

Steel, R.G.D., and J.H. Torrie. 1960. Principles and Procedures of Statistics. McGraw-Hill Book Co., Inc., New York. 481 p.

Wallace, J.D., F.A. Sneva, R.J. Raleigh, and C.G. Rumburg. 1966. Digestibility of chemically cured range forage. Proc. West. Sect. Amer. Soc. Anim. Sci. 17:385-390. 